\title{
Teacher Function in Class: A Literature Review
}

\author{
Abida Ferindistika Putri \\ Department of Educational Administration \\ Universitas Negeri Malang, Indonesia \\ abidafp@gmail.com
}

\author{
Hana Andriningrum \\ Department of Primary Teacher \\ Universitas Negeri Malang, Indonesia \\ hansiphana@gmail.com
}

\author{
Siti Khusnul Rofiah \\ Department of Accounting \\ Universitas Negeri Malang, Indonesia \\ khusnu1280998@gmail.com \\ Imam Gunawan \\ Department of Educational Administration \\ Universitas Negeri Malang, Indonesia \\ imam.gunawan.fip@um.ac.id
}

\begin{abstract}
In order to increase the role of the teacher in the teaching-learning process and student learning outcomes, the teacher is expected to be able to create an effective learning environment and be able to manage the classroom. Because class is a learning environment and is an aspect of the school environment that needs to be organized. This environment needs to be regulated and monitored so that learning activities are directed towards educational goals. A good environment is one that is challenging and stimulates students to learn, provides a sense of security and satisfaction in achieving the expected learning outcomes.
\end{abstract}

Keywords: teacher function, educator, inspirator, motivator, facilitator, evaluator

\section{INTRODUCTION}

The teacher is one of the important elements that must exist besides students. Becoming a teacher is not an easy task. This is because the teacher has a very important role in the education process. The teacher is a central figure, in the hands of the teacher lies the possibility of success or failure in the achievement of learning and teaching goals in school. Therefore, the task and role of the teacher is not only to educate, teach and train, but also how the teacher can also read the class situation and conditions of students in receiving lessons. Sudarwan and Danim (2010) state that the teacher's term is not included in Law Number 20 Year 2003 concerning the National Education System. The word teacher in the law is included in the genus of educators. Actually, teachers and educators are two different things.

The word educator (Indonesian) is the equivalent of the word educator (English). The word educator means educationist or educationalist which means that in Indonesian is an educator, a specialist in the field of education, or an education expert. The word teacher (Indonesian) is the equivalent of the word teacher (English). The word teacher means as person who teach, especially in school, or the teacher is someone who teaches, especially in school. Government Regulation Number 74 Year 2008 concerning Teachers states that teachers are included in: (1) the teacher himself, both the class teacher, the teacher of the field of study, as well as the guidance and counseling teacher, or the career guidance teacher; (2) teachers with additional duties as school principals; and (3) teachers in supervisory positions. The term teacher also includes individuals who carry out guidance and counseling assignments, supervise learning in educational institutions or public and private schools, school technicians, administrators or principals, and school administration personnel (TAS) for administrative matters.

Gunawan (2013) states that the views of traditional Javanese society, socio-culturally the teacher (guru) is a respectable profession. This is revealed from the word "guru" which in Javanese according to kerata basa or jarwa dhosok is short "digugu lan ditiru" (obeyed his orders and imitated his behavior) which means to be adhered to and emulated (Ranggawarsita, 1954). Starting from that base, the teacher is a respected person and profession in traditional Javanese society. They become role models and examples for the community because they have the skills, abilities and behavior that deserve to be set as an example. Therefore, to become a teacher one must meet a number of criteria to meet the ideal picture of traditional Javanese society. The traditional Javanese view of the teacher as mentioned above, of course, also exists in other ethnic groups in Indonesia. In other words, actually the views of the Indonesian people towards the teaching profession are represented from the views of the traditional Javanese community.

The teacher is a respected person and profession in Indonesian society. In the present (modern) socio-cultural view of teachers has shifted, but the teaching profession is still considered honourable and noble in front of the community, because teachers are the vanguard in achieving national goals, namely the intellectual life of the nation (Gunawan, 2013; Gunawan, 2019). It was the teacher who "created" smart, clever people who had become the nation's teachers. Because it has a strategic position and role in national development in the field of education, especially in an effort to educate the life of the nation, it is no different from the traditional period, with other languages and terms in the present time teachers are required to have qualifications, competencies, and professionalism.

So, the teacher's role in developing student personality is very visible. This is where there needs to be an example in the teacher's own personality, which is displayed in everyday life, both in the school or community environment, seen by students or not, the teacher still displays an elegant personality. Learning is carried out by the teacher basically has one goal, namely to print and direct students to be good people, good personality, and smart. This is confirmed by Gunawan 
(2011) who argues that teachers through learning activities are expected to combine the overall potential of students' brains to form meaningfulness (God Spot). All of these potentials are naturally given by God to humans in their position as human beings, human beings as a whole, with all their totality, mind and body. Education needs to be continually improved, optimized and still allows for improvement. So, there needs to be a change in the minds of educators who tend to mere knowledge transfer. Education can eventually return to its nature, which humanizes humanity in their position as human beings.

If the teacher has a good personality, has affection towards students, peace of mind, then becomes a teacher who is missed by his students (Khalifah and Quthub, 2009). The beloved teacher is a person who accepts sincerely and happily - before all things - as a human being. This will make teachers more able to understand their students and interact well with students. A beloved teacher is a teacher who has a friendly nature in interacting with others, understanding others, respecting responsibilities, being disciplined in his attitude and duties, and being able to take initiative and be innovative. Students with good personalities are taught by teachers with good personalities. Students who have bad personalities turn out to be good and successful, conversely students who have good personalities suddenly turn out to be bad. Good or bad student personality is influenced by the personality of the teacher. So before demanding students of good character, it is necessary to develop good character in the teacher.

\section{FUNCTION OF TEACHERS IN CLASS}

When science is still limited, when the discovery of technological results has not developed as great as it is today, the main function of teachers in schools is to convey science as a cultural heritage of the past that is considered useful and should be preserved. Peters stated the duties and responsibilities of teachers include three aspects, namely the teacher as a teacher, the teacher as a guide, and the teacher as the class administrator (Wahyuningsih, 2010).

The teacher, as a teacher, places more emphasis on the task of planning and implementing teaching. Teachers in this task are required to have a set of teaching knowledge and technical skills, in addition to mastering the knowledge or material to be taught.

The teacher as a guide, puts pressure on the task, provides assistance to students in solving the problems they face. This task is an educational aspect because it not only concerns the delivery of knowledge but also involves the development of personality and the formation of the values of students. Teachers as class administrators, have the spatial ability for teaching, and are able to create a learning climate of teaching based on harmonious and healthy human relationships.

Wijaya (2013) states that the function of teachers as educators in the classroom is very many, namely: (1) educators; (2) instructors; (3) mentor; (4) trainers; (5) advisor; (6) class manager; (7) demonstrators; (8) corrector; (9) inspirators; (10) informator; (11) organizer; (12) motivator; (13) initiator; (14) facilitator; (15) innovators; (16) mediators; and (17) evaluator. The following will describe the function of the teacher as an educator in the classroom.

\section{Educator}

The teacher is an educator who becomes a figure, research and identification for students and their environment. Therefore, teachers must have certain personal quality standards that include responsibility, authority, independence, and discipline. The teacher must understand the values, moral norms, and social, and try to behave and act in accordance with these values and norms. Teachers must also be responsible for their actions in the learning process at school as educators, teachers must also dare to make decisions independently related to learning and the formation of competencies and act in accordance with the conditions of students and the environment.

\section{Teachers}

Teaching means giving instructions to others in order to know something (teachings, advice). Teacher means someone who gives instructions so that others know about a doctrine or advice. Teachers as instructors mean that a teacher must help students who are developing to learn something they do not know, form competencies and understand the standard material being learned.

\section{Supervisor}

Guiding in this case can be said to be an activity guiding students in their development by clearly giving steps and directions that are in line with educational goals. This role must be prioritized, because the presence of teachers in schools is to guide children required to become capable adult adults. Without guidance, students will experience difficulties in facing their development. Lack of students' abilities causes more to depend on teacher assistance. But as they mature, the dependence of students decreases, so however guidance from the teacher is needed when students are not able to stand alone (independent).

\section{Coach}

The education and learning process requires training in both intellectual and motor skills, thus requiring teachers to act as trainers. Because without training a student will not be able to demonstrate mastery of basic competencies, will not be proficient in a variety of skills developed in accordance with standard material, must also be able to pay attention to individual differences in students.

\section{Counselor}

The teacher is as an advisor for students, even for parents, even though they don't have special training as an advisor. In order for the teacher to realize his function as an advisor, he must understand the personality and mental psychology, will help the teacher to carry out his function as an advisor.

\section{Class Manager}

The teacher as the class manager should be able to manage the class well, because the class is a place where all students and teachers gather to receive learning 
material from the teacher. Classes that are well managed will support the course of educational interactions. Conversely classes that are not well managed will hinder teaching activities.

Wiyani (2013) states that the quality and quantity of student learning in class is determined by the teacher factor as a class manager. Mastery of theoretical knowledge about learning and teaching skills is the initial capital that must be owned by the teacher as a class manager, henceforth the teacher must understand the concepts and activities in classroom management.

\section{Demonstrator}

The teacher through his role as a demonstrator should always master the material or subject matter that will be taught as well as, always developing it in the sense of increasing his ability in terms of the knowledge he has because this will determine the learning outcomes achieved by his students. For learning materials that are difficult for students to understand, the teacher must try to help them, by demonstrating what is taught, so that what the teacher wants is in line with students' understanding.

\section{Corrector}

The teacher as a corrector must be able to distinguish between good grades and bad ones. Both of these values must be understood in people's lives. Both of these values may have had students and may have influenced it, before students entered school. Because of the different backgrounds of students' lives. All good grades must be maintained by teachers and all bad grades must be removed from the souls of students. If the teacher leaves it alone, it means that the teacher has neglected his role as a corrector, who assesses and corrects all attitudes, behaviors, and actions of students.

\section{Inspirator}

The teacher as an inspiration must be able to provide good inspiration for the progress of learning of students. Learning problems are the main problem of students. The teacher must be able to give instructions (inspiration) on how to learn well. The instructions do not have to be based on a number of good learning theories. The important thing is not the theory, but how to release the problems faced by students.

\section{Informator}

As an informator, teachers must be able to provide information on the development of science and technology, in addition to a number of subject matters for each subject that has been programmed in the curriculum. Good and effective information is needed from the teacher. Misinformation is toxic to students. To be a good and effective informator, language acquisition is the key, supported by the mastery of the material that students will provide. A good informator is a teacher who understands the needs of students and serves students.

\section{Organizers}

As an organizer, is the other side of the role required of the teacher. In this field the teacher has the activities of managing academic activities, compiling school rules, compiling an academic calendar, and so on.
Everything is organized, so that it can achieve effectiveness and efficiency in learning in students.

\section{Motivator}

As a motivator, teachers should be able to encourage students to be passionate and active in learning. In an effort to provide motivation, teachers can analyze the motives behind students' lazy learning and decreased performance in school. Motivation is done by paying attention to the needs of students.

\section{Initiator}

The teacher must be able to be the originator of ideas of progress in teaching education. The current learning process must be improved according to the development of science and technology in the field of education. Not to follow along without the originator of innovative ideas for the advancement of education and teaching.

\section{Facilitator}

The meaning of the facilitator is to provide convenience. Teachers as facilitators should be able to work on learning resources that are useful and can support the achievement of goals and teaching and learning process, whether in the form of resource persons, textbooks, magazines, or newspapers.

\section{Innovator}

Innovator means people who always have new ideas to solve a problem. The teacher translates his past experiences into a meaningful life for students. The teacher's task is to translate valuable policies and experiences into terms or languages that will be accepted by students. Therefore, as a bridge between the older generation and the younger generation, who are also experience translators, the teacher must become an educated person. The teacher is a source of student ideas when he has a problem. In addition, the teacher is also a mover of new ideas in developing the learning process.

\section{Mediator}

As a mediator the teacher must have sufficient knowledge and understanding of educational media in various forms and types, both nonmaterial and material media. The media functions as a communication tool to activate the educational interaction process. The skills in using all media are expected from the teacher which is adjusted to the achievement of the teaching objectives.

\section{Evaluator}

As an evaluator, the teacher is required to be a good and honest evaluator, by giving an assessment that touches on aspects of the personality of students and aspects of the assessment of students' answers when the test. Students who perform well do not necessarily have good personalities. So, the assessment is essentially directed at changing the personality of students to become capable human beings. As an evaluator the teacher not only assesses the product (the results of teaching), but also assesses the process (the course of teaching). Then from both of these activities, will get feedback.

Hoyle suggests a set of teacher roles which are simultaneously displayed in the classroom (Safitri, 2014). 
The roles are: (1) community representatives; (2) judge (gives a grade); (3) resources (processes, knowledge, and skills); (4) helper (giving guidance for students' difficulties); (5) detective (finding rule breakers); (6) divorce (settling disputes among students); (7) object identification for students; (8) antidote to anxiety (helping students control lust); (9) supporting the strength of the ego (helping students to have confidence in themselves); (10) group leaders (forming the group climate); (11) a substitute for parents (acting as a place to complain about young children); (12) targets of student anger (acting as objects of aggression arising from frustration created by adults); (13) friends and trust (building warm relationships with students and mutual trust); and (14) objects of attention (adhere to the psychological needs of students).

\section{TEACHER FUNCTION IN LEARNING}

Learning activities are academic activities that are universal. There are many variables that can influence the learning process. The teacher is a key factor in learning activities. Teachers today are faced with increasingly heavy demands, especially to prepare students to be able to face the dynamics of change that are developing rapidly (Gunawan, 2013). The changes that occur are not only related to changes in science and technology, but also touches on the shifting aspects of values and morals in social life. Learning does not stop at the cognitive level, but touches on the level of internalization, and real practice in the daily lives of students in the community (Gunawan, 2013).

This is in accordance with Ki Hadjar Dewantara life teachings, "Tringa" which includes ngerti, ngrasa, and nglakoni (understanding, feeling, and doing), reminding all teachings, the ideals of life that we profess require understanding, awareness and sincerity in its implementation. Knowing and understanding alone is not enough, if you do not feel, realize, and have no meaning if you do not implement and do not fight for. Likened to science without charity like a tree that does not bear fruit. A teacher, according to Yoesoef, has three main tasks, namely professional tasks, human tasks, and social tasks (Wardani, 2010). The professional tasks of a teacher are to carry on or transmission knowledge, skills and other similar values that are not yet known to students and should be known by students.

Human tasks are tasks that help learners to be able to fulfil the main tasks and the human future as well as possible. Human tasks are self-transformation, selfidentification and self-understanding. Teachers should with education be able to help students to develop thinking or reasoning in such a way that they are able to participate creatively in the process of cultural transformation towards civilization for the improvement of their own lives and the lives of the entire society in which they live. The social task is a consequence of the teacher being a good citizen, taking part and implementing the Pancasila and the 1945 Constitution.

When a teacher in carrying out learning activities, the teacher will play three functions, namely instructional function, educational function, and managerial function. The instructional function is related to the teacher's role as a teacher, that is, a person who gives instructions in the form of knowledge to students. The educational function is related to the teacher's role as an educator, namely to educate students to have a strong character. And managerial functions related to the teacher's role as class manager, which regulates the needs of class administration to support the implementation of learning.

\section{Instructional Function}

Throughout teacher history, the traditional teacher's tasks or functions are teaching (to teach), namely: (1) conveying a number of statements and facts to students; (2) assigning tasks to them; and (3) correct or check it. This instructional function is still always prioritized by almost everyone called a teacher, and this instructional function is still dominant in the great career of the teacher. This instructional function is a conscious effort by the teacher to help students or students, so that they can learn according to their needs and interests.

\section{Educational Functions}

The function of the teacher is not just teaching, but also must educate (to educate). This educational function must be the central function of the teacher. Every teacher in this function must try to educate his students to become adult humans. This is in line with the nature of education, namely education is a process of maturing humans. The teacher is in charge of educating his students. Langeveld (1996) states that educating is giving conscious and deliberate help to a child (who is not yet an adult) in his growth toward maturity, in the sense of being able to stand alone and take moral responsibility for all his actions according to his own choice.

\section{Managerial Function}

The teacher's leadership or managerial function in modern school administration is not only limited in the classroom, but also involves the situation of the school where he works, even involving activities in the community. The teacher has an integral role and function that is inseparable, between the ability to educate, guide, teach and train. These four abilities are integrative abilities that cannot be separated from one another. The instructional function of the teacher is teaching, that is, conveying a number of information and facts to students, giving assignments to them, correcting or examining them, planning teaching programs and implementing programs that have been prepared, and evaluating after the program is implemented.

Teachers must have certain personal quality standards, which include responsibility, authority, independence, and discipline. The teacher as a manager has four functions, namely: (1) planning learning objectives; (2) organizing as a source of learning to realize learning goals; (3) leading, including motivation, encouraging, and stimulating students; and (4) supervising everything whether it is functioning as it should or not, in the context of achieving goals.

\section{CONCLUSION}

Professional teachers are educators who have professional authority in educating, teaching, guiding, directing, training, assessing and evaluating students. As an ideal and professional figure, the teacher has the duty and responsibility for his behavior and actions and has a 
fundamental role, namely the teacher must be able to place himself as bringing changes in instilling noble values to students in order to become human beings of quality and have faith in God.

\section{REFERENCES}

[1] Gunawan, I. 2011. Merekonstruksi Fitrah Pendidikan. Komunikasi, Majalah Kampus Universitas Negeri Malang Tahun 33 Nomor 276 September - October 2011, p. 32.

[2] Gunawan, I. 2013. Revitalisasi Karakter Guru menurut Filosofis Jawa: Sebuah Gagasan Mengembangkan Kepribadian Siswa. Proceeding International Seminar on: Local Wisdom and Character Education for Elementary School Students, IKIP PGRI MADIUN, Madiun, 6 April, p. $48-62$.

[3] Gunawan, I. 2019. Manajemen Kelas: Teori dan Aplikasinya. Jakarta: Rajawali Pers.

[4] Khalifah, M., and Quthub, U. 2009. Menjadi Guru yang Dirindu. Surakarta: Ziyad Books.

[5] Langeveld, M. J. 1996. Pedagogik Teoritis dan Sistematis. Bandung: Jemmars.

[6] Law Number 20 Year 2003 concerning the National Education System. Jakarta: Fokus Media.
[7] Ranggawarsita, R. N. 1954. Wirid Hidajat-Djati. Surabaya: Trimurti.

[8] Safitri, D. 2014. Peran dan Fungsi Guru dalam Kelas. $\begin{array}{llll}\text { Retrieved } 23 & \text { July } 2019, & \text { from }\end{array}$ http://dyaniedewiexs.blogspot.com/2014/06/peran-danfungsi-guru-dalam-kelas.html.

[9] Sudarwan, D., and Danim, Y. 2010. Administrasi Sekolah dan Manajemen Kelas. Bandung: Pustaka Setia.

[10] Wahyuningsih, S. 2010. Optimalisasi Pengelolaan Moving Class di SMA Semesta Semarang (Studi Fungsi Pengelolaan Kelas). Thesis. Semarang: Institut Agama Islam Negeri Walisongo Semarang.

[11] Wardani, K. 2010. Peran Guru dalam Pendidikan Karakter menurut Konsep Pendidikan Ki Hadjar Dewantara. Proceedings of The 4th International Conference on Teacher Education, Join Conference UPI \& UPSI Bandung, Indonesia, PGSD FKIP Universitas Sarjanawiyata Tamansiswa Yogyakarta, 8-10 November.

[12] Wijaya, I. 2013. Fungsi atau Peran Guru didalam Kelas. Retrieved 23 July 2019, from https://masukmts.wordpress.com/2013/04/03/fungsi-atauperan-guru-di-dalam-kelas-2/)

[13] Wiyani, N. A. 2013. Manajemen Kelas: Teori dan Aplikasi untuk Menciptakan Kelas yang Kondusif. Jogjakarta: Ar-Ruzz Media. 